\title{
Capacity Building for Quality Enhancement in Higher Education
}

\author{
P. M. Suresh Kumar \\ Srinivas Institute of Management Studies, Srinivas University Pandeshwar, \\ Mangalore - 575001, India \\ E-mail: sureshpmsk@rediffmail.com
}

Type of the Paper: Research Paper.

Type of Review: Peer Reviewed.

Indexed in: OpenAIRE.

DOI: http://dx.doi.org/10.5281/zenodo.1042112.

Google Scholar Citation: IJMTS

\section{How to Cite this Paper:}

Suresh Kumar, P. M. (2017). Capacity Building for Quality Enhancement in Higher Education. International Journal of Management, Technology, and Social Sciences (IJMTS), 2(2), 84-92. DOI: http://dx.doi.org/10.5281/zenodo.1042112.

International Journal of Management, Technology, and Social Sciences (IJMTS) A Refereed International Journal of Srinivas University, India.

(C) With Authors.

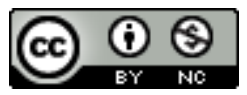

This work is licensed under a Creative Commons Attribution-Non Commercial 4.0 International License subject to proper citation to the publication source of the work.

Disclaimer: The scholarly papers as reviewed and published by the Srinivas Publications (S.P.), India are the views and opinions of their respective authors and are not the views or opinions of the SP. The SP disclaims of any harm or loss caused due to the published content to any party. 


\title{
Capacity Building for Quality Enhancement in Higher Education
}

\author{
P. M. Suresh Kumar \\ Srinivas Institute of Management Studies, Srinivas University Pandeshwar, \\ Mangalore - 01, India \\ E-mail: sureshpmsk@rediffmail.com
}

\begin{abstract}
Higher education institutions strive to produce quality professionals, who would be intellectually robust, emotionally balanced, and economically productive, socially committed and spiritually satisfied so that they make meaning in their lives and contribute to the society. Teachers have a big role in maintaining this. Teacher quality influences curriculum, provides leadership, and promote student progression. Curriculum delivery and pedagogy should incorporate multitude of learning experiences and innovative learning methodologies. So much so the faculty should be exposed to advance knowledge and skill through a variety of ways which would be mutually complementary for both the teacher and the taught. Their capacities should be developed and all the more periodically recharged for sustained results. This paper discusses capacity building through establishing sustainable mechanisms to improve quality in teaching as reflected in the values and culture of the institution.
\end{abstract}

Keywords: Capacity building, Quality enhancement, Higher education.

\section{INTRODUCTION :}

Maintaining the profile of students and teachers is a major challenge for higher educational institutions. Teacher quality influences curriculum, provides leadership, and promote student progression. With this in view, institutions resort to a lot of ways by which they can attract, motivate and maintain high standards of excellence among teachers. Curriculum design and delivery should take into account the growing needs, changing interests and pace of learners. In order to meet this, pedagogy should incorporate multitude of learning experiences and innovative learning methodologies. So much so the faculty should be exposed to advance knowledge and skill through a variety of ways which would be mutually complementary for the teacher and the taught. Academic improvements and teacher quality up-gradation is best possible if mechanisms are put in place which would monitor the quality of teaching-learning. Side by side, ways and means of enhancing faculty capacity becomes important. A variety of ways could be introduced to build the capacity of the faculty [1-34].

\section{EXPOSURE TO ADVANCE KNOWLEDGE AND SKILLS OF FACULTY :}

Plenty of avenues are open to adopt learning. It is important because such exposures are a vital source to upgrade knowledge and skills beyond the confines of curriculum. Students and faculty obtain opportunities to advance level of knowledge and skills through such means.

$\checkmark$ Seminars - Seminars, symposium and conferences conducted periodically encourage student participation. Students also participate in similar programmes by other institutions.

$\checkmark$ Workshops - Workshops/Trainings are organized periodically.

$\checkmark$ Guest lectures - Experts from industry \& NGO deliver the lectures on various 
ongoing issues and current happenings in the corporate world/community to provide real time information and knowledge to the students.

$\checkmark$ Blended learning - In addition to chalk and talk method of teaching, the faculty members use the IT enabled learning tools such as PPT, Video clippings, Audio system, Online sources, Simulation software, Communication lab and Decision making games and Field work conference to expose the students to combine advanced knowledge with practical learning.

$\checkmark$ Certificate Programmes: A large number of Certificate programmes are offered to build employability skills in students and reduce the gap between curriculum and industry.

$\checkmark$ Research Based Projects : All courses offer Research based projects for preparing dissertation through guidance and supervision.

$\checkmark$ Practical Assignments : Assignments are required to be submitted by the students on various topics which is within the curriculum. This is taken for calculating internal assessment marks.

\section{MONITORING QUALITY OF TEACHING-LEARNING :}

It is important that the institution has built in mechanisms for monitoring and evaluating the quality of teaching-learning. This practice focuses on ensuring quality and capacity of the faculty. It can be implemented through a variety of means.

$\checkmark$ Conducting Internal Examinations : Internal examinations conducted at regular intervals as planned in the academic calendar at the beginning of the calendar year/semester will reveal the performance of students which will indicate the extent of preparedness developed, syllabus completion on time through direct involvement of faculty.

$\checkmark$ Result Analysis : The results of the final examinations could be analysed through segregating students in terms of their achievements as reflected in the marks scored in each examination. The faculty who has been engaging classes for the concerned subjects will own responsibility for the poor performance of the students.

$\checkmark$ Feedback from Students: Collecting feedback from students in a properly designed format at the end of every semester and reviewed by the Head of the institution is shared with the concerned faculty for rectification and improvement. This serves the function of exit interview.

$\checkmark$ Class Visits : A direct and first hand appraisal of the classes is obtained during surprise visits to the classes in progress by competent authority.

$\checkmark$ IQAC: IQAC plays a great role in closely monitoring and evaluating the quality of teaching- learning processes.

$\checkmark$ CCD Monitoring of the Classes : Use of modern technology such as closed circuit camera help to maintain discipline and regularity of classes which is conducive to effective learning.

$\checkmark$ Suggestion Box : There are students who hesitate to open-up in free forums. Such students can make use of the suggestion box. Suggestions, among other things could include quality of teaching of the various subjects.

$\checkmark \quad$ End User Benefit Documentation :This is a practice of monitoring the classes while in progress, by visiting the classes and recording the signature of faculty. This ensures that the end users are benefitted.

\section{CAPCITY BUILDING OF FACULTY :}

Although teaching-learning is a mutually complementary process, it is presumed that quality teaching contributes to quality learning. Therefore ways and means of enhancing faculty capacity becomes important. In general training programmes serve to build the capacity of the faculty in the entire range of curriculum handling, knowledge management and student evaluation.

(1) Technology based data analysis: The faculty members acquire competence in technology based data analysis through use of 
SPSS, simulation etc. during Faculty Development programmes.

(2) Counselling and Mentoring: Training programmes conducted to train the faculty in counselling, serve to improve their capacity to handle student problems arising out of stress, neglect, loneliness and domestic difficulties.

(3) Handling new curriculum : Faculty Training Programmes organized by the institution shall discuss weightage of each topic relevant references, approaches and methods, pattern of questions, background knowledge required to be created to learn etc. Teaching plans are required to be prepared and study material to be developed by individual faculty. Before taking a new subject during a particular year by a faculty, discussion is generated in the training programme. The depth and framework of the subject form the content of the discussion.

(4) Content/Knowledge management : Faculty members identify, acquire and transform the relevant information into knowledge. The sources of information include books, periodicals, journals, video clippings, databases etc. These information are tailored suitably to prepare study materials and transformed in the form of lectures, PPT presentations, and other methods etc.

(5) Selection, Development and Use of Enrichment materials: Faculty training programmes provide a spectrum of supplementary materials which serves to be used as enrichment materials. Such for example are Open Source Courseware, NPTEL Lectures, Freely downloadable books from internet etc. The competency to dovetail such materials is acquired in the training programmes.

(6) Student Assessment and Evaluation: Faculty training programmes help the faculty in equipping them for fair and transparent assessment of the students

(7) Cross cutting issues : Cross-cutting issues such as gender, environment, climate change etc. are discussed in the Faculty training programme due to their significance in the present context for human sustenance and survival. Subject experts in this area are brought in to deliver speeches on relevant topics concerning the above.
(8) Audio Visual Aids/multimedia : Faculty training programmes include certain sessions on usage of audio-visuals and multimedia. Live demonstrations are performed by the trainers who take care of such systems.

(9) Teaching learning material-Development, Selection and Use :Through training/induction programmes, faculty members develop skill to prepare and use teaching-learning materials such as session-wise teaching plan and study materials according to the syllabus, Question bank, Business cases and PPT presentations.

\section{MEASURES OF RECHARGING :}

1. Providing Opportunity to teach new Subjects : Teachers are encouraged to teach new subjects every year so that they enjoy the freedom of choosing the subjects liked and avoid monotony in teaching same subject continuously for many years. This also helps in enhancing their knowledge capacities widely and makes them competent.

2. Providing support for technology based information collection : Based on various trainings provided to acquire new knowledge through technology based information collection, the obsolete methods/techniques of faculty members are replaced.

3. Incorporation of Value added Chapter in each subject: Over and above the prescribed syllabus teachers choose to add a few sessions of value addition in each subject. This helps to enrich their job through discovering recent developments in the subject.

4. Encouragement for innovative teaching Practices: Teachers should be encouraged to bring in creativity and innovation in teaching practices. Such for example, are 'Entry test and Summarization' by students during each class, new and relevant business cases and business games aimed at increased participation of students etc.

5. Curriculum development : Providing opportunity for participating in curriculum development, serves to recharge the teachers.

6. Introducing Certificate courses: Through Certificate programmes designed to meet the latest trends in the industry, teachers get opportunity to choose, learn and deliver subjects 
of their choice.

7. Research Centre In-charge: Identified emerging areas could be used for promoting research by forming Research Centres and expertise of the faculty may be utilized in the capacity of in-charge of research centre.

8. Sabbatical Leave : A policy to grant study leave for pursuing Ph.D. research on full time. Protecting the job and availing benefits.

9. Support for Research : This persuades faculty to earn higher degrees by pursuing research.

10. Research Grants : Through promoting the efforts to obtain funded projects and research grants from appropriate funding agencies the institute can build capacity and profile of the faculty. A policy to provide seed money for research is also encouraging.

\section{Teaching Experience in other National} Institutions/ specialized Programmes :
Appointing experienced teachers who have qualified from National Institutions and encouragement to gain exposure by participating in various programmes held in National Institutions are ways to overcome redundancy.

12. Industrial Engagement: Appointing teachers who have experience in industry/related fields and promoting consultancy services by the teachers provide advantage to gain experience without being away from the job.

\section{VALUES IN INSTITUTIONS CULTURE OF DEVELOPING FACULTY POTENTIAL:}

The institution grooms leadership at different levels. Such for example are individual level, job related level and career orientation level. This is intended to bring about desired outcome in consonance with the values in the institution's culture (Table 1).

Table 1 : Levels of leadership and expected outcome through different ways of grooming.

\begin{tabular}{|c|c|c|c|}
\hline S. No. & $\begin{array}{l}\text { Levels of } \\
\text { leadership }\end{array}$ & Ways of grooming & Outcome \\
\hline 1 & Individual level & $\begin{array}{l}\text { 1. Open communication } \\
\text { 2. Trust } \\
\text { 3. Mutual respect } \\
\text { 4. Cooperation } \\
\text { 5. Collaboration } \\
\end{array}$ & $\begin{array}{l}\text { Clear thinking } \\
\text { Better followers } \\
\text { Getting on well } \\
\text { Learn from each other } \\
\text { Task simplified }\end{array}$ \\
\hline 2 & Job related & $\begin{array}{l}\text { 1. Rewards } \\
\text { 2. Competition } \\
\text { 3. Motivation } \\
\text { 4. Guidance } \\
\text { 5. Team spirit }\end{array}$ & $\begin{array}{l}\text { Identification with purpose } \\
\text { Desire for better } \\
\text { More output } \\
\text { Listen to advise } \\
\text { Sense of togetherness }\end{array}$ \\
\hline 3 & $\begin{array}{l}\text { Career } \\
\text { Orientation }\end{array}$ & $\begin{array}{l}\text { 1. Providing adequate opportunity } \\
\text { 2. Entrusting responsibility } \\
\text { 3. Creating confidence } \\
\text { 4. Building skills } \\
\text { 5. Upgrading knowledge } \\
\text { 6. Increasing job satisfaction } \\
\text { 7. Excelling in career }\end{array}$ & $\begin{array}{l}\text { Create growth } \\
\text { More accountability } \\
\text { Belief in self } \\
\text { Strive for perfection } \\
\text { Thorough understanding } \\
\text { Pleasure in doing work } \\
\text { Self-actualization }\end{array}$ \\
\hline
\end{tabular}
Institution, the way they wish it to be.

The following six values with corresponding practices are to be embedded in the Institute's culture of developing the full potential of its faculty members and students.

1. Self Responsibility: Individual takes responsibility of their job, team, function,
2. Authentic Communication: Individual communication is open, honest, and transparent. 3. Trust: Individuals feel safe enough to try out new behaviors and take risks without fear.

4. Personal and group process skills: 
Individuals and Institutions have established protocols and developed skills which are regularly deployed to resolve interpersonal issues that come across and are resolved quickly and clearly.

5. Learning and Growing: Individuals are encouraged and rewarded to work on the real growth issues necessary for professional and personal development within the framework of the organization. Individuals are never mutually challenging, but supporting each other to develop and grow.

Table
6. Caring: The organizational leadership demonstrate in tangible ways concern for individual employees well being. Employees feel valued and are inspired to put in their best effort.

\section{INSTITUTIONAL MECHANISM FOR FACULTY IMPROVEMENT :}

The institution should have mechanisms to continuously review the teaching-learning process as given in table 2. Such for example are as follows :

Table 2 : Institutional mechanism for faculty improvement.

\begin{tabular}{|c|c|c|c|}
\hline $\begin{array}{l}\text { S. } \\
\text { No. }\end{array}$ & Mechanisms & $\begin{array}{l}\text { Structure, methodologies of } \\
\text { operation }\end{array}$ & Outcome \\
\hline 1 & Teachers Diary & $\begin{array}{l}\text { Date wise, time wise, classes } \\
\text { according to the time table is } \\
\text { recorded in teachers dairy. } \\
\text { This gives a clear picture that the } \\
\text { classes are conducted } \\
\text { systematically }\end{array}$ & $\begin{array}{l}\text { Faculty realizes importance } \\
\text { of adhering to the schedules. }\end{array}$ \\
\hline 2 & Attendance Register & $\begin{array}{l}\text { The number of classes taken } \\
\text { versus the number of working } \\
\text { days gives a direct measure of } \\
\text { teaching input. }\end{array}$ & $\begin{array}{l}\text { Faculty realizes the } \\
\text { importance of the classes. }\end{array}$ \\
\hline 3 & Student Feedback & $\begin{array}{l}\text { Appraisal forms are distributed to } \\
\text { the students on the last working } \\
\text { day of the semester. This is } \\
\text { confidently collected and passed } \\
\text { on to the head of the institute for } \\
\text { review. }\end{array}$ & $\begin{array}{l}\text { Faculties identify need for } \\
\text { improvement. }\end{array}$ \\
\hline 4 & Performance appraisal & $\begin{array}{l}\text { Performance self appraisal is } \\
\text { done by the faculty. Against each } \\
\text { of the appraisal items, the head of } \\
\text { the institute marks his assessment } \\
\text { in the form of grade point. }\end{array}$ & Faculty identify weakness \\
\hline 5 & Result analysis & $\begin{array}{l}\text { Result analysis is done for finding } \\
\text { out the percentage of marks } \\
\text { scored by the students in each of } \\
\text { the subjects. This together is } \\
\text { treated as a measure of the } \\
\text { concerned faculties teaching } \\
\text { efficiency. }\end{array}$ & $\begin{array}{l}\text { Faculty realizes need for } \\
\text { improvement. }\end{array}$ \\
\hline 6 & $\begin{array}{l}\text { Meetings with the } \\
\text { faculty }\end{array}$ & $\begin{array}{l}\text { Meetings with faculty are } \\
\text { conducted by Management/ Head } \\
\text { of the institute. Poor performance }\end{array}$ & $\begin{array}{l}\text { Faculty develops increased } \\
\text { accountability. }\end{array}$ \\
\hline
\end{tabular}




\begin{tabular}{|l|l|l|l|}
\hline & $\begin{array}{l}\text { like low pass percentage and poor } \\
\text { marks are sought explanation. }\end{array}$ & \\
\hline
\end{tabular}

\section{CONCLUSION :}

Institutional commitment to build capacity of its faculty is embedded in its culture as reflected in the values they uphold. Punctuality, adhering to schedules, accountability in achieving results and responding to feedback through positive changes are the outcome of various mechanisms adopted. These mechanisms trigger certain processes which promote the academic ambience and work culture. The plethora of measures to build the capacity of the faculty and recharge them suggested here are indicative of the enormous scope and its contribution to quality enhancement through capacity building in higher education.

\section{REFERENCES :}

[1] Suresh Kumar, P. M. (2016). Curriculum Enrichment for Learning Outcomes in Higher Education. International Journal of Scientific Research and modern Education (IJSRME). 1(2). 175-183.

[2] Suresh Kumar, P. M., (2016). Leadership Development and Quality Enhancement in Higher Education. International Journal of Advanced Trends in Engineering and Technology (IJATET). 1(1). 49-53. DOI : https://zenodo.org/record/225699.

[3] Suresh Kumar, P. M. (2016). Stakeholder Perception and Academic Improvements in Higher Education. International Journal of Advanced Trends in Engineering and Technology (IJATET). 1(1), 10-14.

[4] Suresh Kumar, P. M. (2017). Community Engagement Initiatives in Higher Education,. International Journal of Engineering Research and Modern Education (IJERME), 2(1), 80-85.

[5] Aithal, P. S. \& Suresh Kumar, P. M. and Deekshitha, (2015). Societal Expectation and Institutional Accountability In Higher Education. International Journal of Management, IT and Engineering (IJMIE), 5(7), 361-373, DOI : http://doi.org/10.5281/zenodo.267021.
[6] Aithal, P. S., Suresh Kumar, P. M. and Pavithra Kumari, (2015). Methods and Approaches for Employability Skill Generation In Higher Educational Institutions. International Journal of Management, IT and Engineering (IJMIE), 5(7), 390-410. DOI: http://doi.org/10.5281/zenodo.267044.

[7] Srinivas Rao, A., Suresh Kumar, P. M. \& Aithal, P. S. (2015). Strategic Planning in Higher Education Institutions : A Case Study of SIMS - Vision 2025. International Journal of Educational Science and Research, 5(2) 29-42. DOI: http://doi.org/10.5281/zenodo.61589.

[8] Aithal, P. S., Srinivas Rao, A. \& Suresh Kumar, P. M. (2015). How Innovations and Best Practices can Transform Higher Education Institutions : A case study of SIMS. International Journal of Management (IJM), 6(2), 83 - 98. DOI: http://doi.org/10.5 281/zenodo.61594.

[9] Aithal, P. S. and Suresh Kumar, P. M., (2015). Enhancement of Graduate attributes in Higher Education Institutions through Stage Models. IMPACT: International Journal of Research in Business Management, 3(3), 121 - 130. DOI: http://doi.org/10.5281/zenodo.61640,

[10] Aithal, P. S. and Suresh Kumar, P. M., (2015). Quality Enhancement in Higher Education Institutions : A case study of SIMS. International Journal of Multidisciplinary Research and Development, 2(5), 18-31. DOI: http://doi.org/10.5281/zenodo.266940.

[11] Aithal, P. S. and Suresh Kumar, P. M. (2015). Applying SWOC Analysis to An Institution Of Higher Education. International Journal of Management, IT and Engineering (IJMIE), 5(7), 231-247. DOI http://doi.org/10.5281/zenodo.163425. 
[12] Aithal, P. S. and Suresh Kumar, P. M., (2016). Student Performance and Learning Outcomes in Higher Education Institutions. International Journal of Scientific Research and Modern Education (IJSRMA). 1(1), 674 - 684, DOI : http://doi.org/10.5281/zenodo.160944.

[13] Aithal, P. S. and Suresh Kumar, P. M., (2016). Catering Stduent Enrollment and Retaining Diversity in Higher Eduction Institutions. International Journal of Engineering Research and Modern Education (IJERME), 1(1), 565 - 577. DOI : http://doi.org/10.5281/zenodo.160939.

[14] Aithal, P. S. and Suresh Kumar, P. M. (2016). Academic Support through Information System : Srinivas Integrated Model. International Journal of Scientific Research and Modern Education (IJSRME). 1(1), 376-384. DOI : http://doi.org/10.5281/zenodo.160976.

[15] Aithal, P. S. and Suresh Kumar, P. M., (2016). Maintaining Teacher Quality in Higher Education Institutions. International Journal of Current Research and Modern Education (IJCRME). 1(1), 701-711. DOI : http://doi.o rg/10.5281/zenodo.160946.

[16] Aithal, P. S. and Suresh Kumar, P. M., (2016). Teaching-Learning Process in Higher Education Institutions. International Journal of Multidisciplinary Research and Modern Education (IJMRME). 2(1), 662676.

DOI

http://doi.org/10.5281/zenodo.160956.

[17] Aithal, P. S. \& Suresh Kumar, P. M. (2016). Analysis of Choice Based Credit System in Higher Education. International Journal of Engineering Research and Modern Education (IJERME), 1(1), 278284. DOI http://doi.org/10.5281/zenodo.161046.

[18] Aithal, P. S. and Suresh Kumar, P. M., (2016). Student Evaluation and Reforms in Higher Education Institutions. International Journal of Multidisciplinary Research and Modern Education (IJMRME), 2(1), 652661. http://doi.org/10.5281/zenodo.160932.

[19] Prithi Rao, and Aithal, P. S. (2016). Green Education Concepts \& Strategies in Higher Education Model. International Journal of Scientific Research and Modern Education (IJSRME), 1(1), 793-802. DOI : http://doi.org/10.5281/zenodo.160877.

[20] Shubrajyotsna Aithal \& Aithal, P. S., (2016). Student Centric Learning through Planned Hardwork - An Innovative Model. International Journal of Scientific Research and Modern Education (IJSRME), 1(1), 886-898. DOI: http://doi.org/10.5281/zenodo.61830.

[21] Aithal, P. S. (2015). Teaching through Entry Test \& Summarization - An Effective Classroom Teaching Model in Higher Education Training. International Journal of Scientific Research and Education, 3(3), $3022 \quad-\quad 3027 . \quad$ DOI : http://doi.org/10.5281/zenodo.61637.

[22] Aithal, P. S. (2015). Internal Quality Assurance Cell and its Contribution to Quality Improvement in Higher Education Institutions : A Case of SIMS. GE International Journal of Management Research (IJMR), 3(5), 70-83, DOI: http://doi.org/10.5281/zenodo.266808.

[23] Aithal, P. S. (2015). Strategy Development and Deployment in Higher Education Institutions. Elixir International Journal, 84, $33594 \quad-\quad 33597, \quad$ DOI: http://doi.org/10.52 81/zenodo.266779.

[24] Aithal, P. S. (2015). Strategies to be adopted in Higher Education Institutions to Enhance Admission Demand. International Journal of Extensive Research, 5, 9-25. DOI: http://doi.org/10.5281/zenodo.268530.

[25] Aithal, P. S. (2015). Faculty Empowerment Strategies in Higher Education Institutions. International Journal of Management, IT and Engineering (IJMIE), 5(7), 108-115. DOI: http://doi.org/10.5281/zenodo.266967.

[26] Aithal, P. S. (2015). Teaching through 
Entry Test \& Summarization - An Effective Classroom Teaching Model in Higher Education Training. International Journal of Scientific Research And Education, 3(3), 3022 - 3027, DOI : http://doi.org/10.5281/zenodo.61637.

[27] Reshma \& P. S. Aithal, (2015). Quality Enhancement in Office Management of Higher Education Institutions through Innovations \& Best Practices. International Research Journal of Business \& Management, 8(5), 16 - 27, DOI: http://doi.org/10.5281/zenodo.61638.

[28] Aithal, P. S. \& Shubhrajyotsna Aithal, (2015). An Innovative Education Model to realize Ideal Education System. International Journal of Scientific Research and Management (IJSRM), 3(3), 2464 2469,

DOI: http://doi.org/10.5281/zenodo.61654.

[29] Aithal, P. S. \& Suresh Kumar, P. M. (2017). Challenges and Opportunities for Research \& Publications in Higher Education. International Journal of Scientific Research and Modern Education (IJSRME), 2(1), 42-49. DOI: http://dx.doi.org/10.5281/ZENODO.4 00619.

[30] Suresh Kumar, P. M. (2017). Adoption of Technology and Augmentation of Resources for Teaching-Learning in Higher Education. International Journal of Management, Technology, and Social Sciences (IJMTS), 1(1), 63-69. DOI
: http://dx.doi.org/10.5281

/ZENO DO.821352.

[31] Suresh Kumar, P. M. (2017). Academic Audit and Quality Assurance in Higher Education. International Journal of Management, Technology, and Social Sciences (IJMTS), 2(2), 61-68. DOI: http://dx.doi.o rg/10.5281/zenodo.1038496.

[32] Pradeep M. D. \& Ravindra B., (2016). Review on the Gender Sensitive Women Education- Legal Revolution in Higher Education. International Journal of Management, Technology, and Social Sciences (IJMTS), 2(1) 53-65. DOI: http://dx.doi.org/10.5281/zenodo.821378.

[33] Shreepathy Ranga Bhatta. B, \& Varun Kumar, S. G. (2017). A Study of Student Perception on Printed Study Material Distribution Model at Srinivas Institute of Management Studies. International Journal of Management, Technology, and Social Sciences (IJMTS), (ISSN: Applied), 2(1), 66-74.

DOI: http://dx.doi.org/10.5281/zenodo.821579.

[34] Suresh Kumar, P. M. (2017). Academic Audit and Quality Assurance in Higher Education. International Journal of Management, Technology, and Social Sciences (IJMTS), 2(2), 61-68. DOI: http://dx.doi.org/10.5281/zenodo.1038496. 